\title{
CORRESPONDENCE
}

\section{SENILE ENTROPION AND ECTROPION}

\section{To the Editorial Committee of the BRITISH JouRnal of OPHTHALMOLOGY}

SIRS,-In the February 1966 issue of the Journal, in a paper on "The Mechanics and Histology of Senile Entropion", Drs R. Dalgleish and J. L. S. Smith refer to a surgical technique employed by one of the authors with a view to giving good support to the lid through the horizontal traction exerted by two triangular flaps.

I write to point out that this operation was originally described by me in 1959 , in an article entitled "V-Z Procedure for the Correction of Senile Ectropion", where I stated specifically that it can be used with advantage in those cases of senile entropion which present a lengthening of the lower lid border. A confrontation of Figs 2 to 4 from my paper with Fig. 3 from that of Dalgleish and Smith will readily bear out this assertion. I should add, perhaps, that my paper appeared, of all places, in the British Journal of Ophthalmology itself.

Yours faithfully,

Casilla de Correo 301,

Alberto UrRets-Zavalía, Jr.

CóRdoba, Argentina,

May 10, 1966.

\section{REFERENCES}

Dalgleish, R., and Smith, J. L. S. 1966. Brit. J. Ophthal., 50, 79.

URRETS-ZAVALfA, A. (1959). Ibid., 43, 521.

\section{NOTES}

\section{European Ophthalmic Pathology Society May, 1966}

The European Ophthalmic Pathology Society held its fifth annual meeting in Geneva from May 26 to 29, 1966. Prof. I. Michaelson of Israel was the honoured guest. This year's host and hostess, Prof. Jean Babel and Mme Babel, had most successfully organized a full scientific and social programme, which began with a welcome-party at their home. The scientific sessions were held at the Musée de l'Athénée. Prof. and Mme Franceschetti gave a party for the members, guests, and wives, and the next evening the annual dinner was held at the Parc des Eaux-Vives. At the business meeting Dr. W. Manschot (Holland) was elected President, Dr. A. Brini (France) became corresponding secretary, and Dr. A. Hamburg (Holland) was elected to the council.

The next meeting is to be held in Rotterdam in the summer of 1967 at the invitation of Dr. Manschot, who will, therefore, also hold the office of organizing secretary. During the meeting Prof. Norman Ashton, the retiring president, was elected honorary life president of the society.

The 27 members who attended the meeting were:

\footnotetext{
Dr. S. Ry Andersen (Denmark)

Prof. N. Ashton (Gt. Britain)

Dr. J. Audibert (France)

Prof. J. Babel (Switzerland)

Dr. R. Barry (Gt. Britain)

Prof. P. Bec (France)

Dr. B. A. Bembridge (Gt. Britain)
}

Prof. J. Böck (Austria)

Dr. A. Brini (France)

Prof. J. Casanovas (Spain)

Dr. C. Cook (Gt. Britain)

Dr. P. Dhermy (France)

Prof. H. Fanta (Austria)

Prof. G. Gunther (E. Germany) 